Огляди літератури, оригінальні дослідження, погляд на проблему

удК 616.24-002.5:615.28.015.8:614.1(477.84)

$\mathrm{DOI}$

\title{
МУЛЬТИРЕЗИСТЕНТНИЙ ТУБЕРКУЛЬОЗ ЗА ДАНИМИ ОБЛАСНОГО ПРОТИТУБЕРКУЛЬОЗНОГО ДИСПАНСЕРУ
}

\author{
๑С. І. Корнага, І. Т. П'ятночка, Н. В. Тхорик \\ ДВНЗ «Тернопільський державний медичний університет імені І. Я. Горбачевського МОз України»
}

РЕЗЮМЕ. У статті представлений аналіз медичних карт стаціонарних хворих на мультирезистентний туберкульоз, які перебували на стаціонарному лікуванні в обласному протитуберкульозному диспансері у 20052014 роках, а також наведені причини значного почастішання цієї небезпечної форми захворювання.

КЛЮчОВІ СЛОВА: мультирезистентний туберкульоз, санпросвітня робота, летальність.

Вступ. За останні роки на тлі поступової стабілізації епідемічної ситуації надзвичайно велику загрозу становить поширення мультирезистентного туберкульозу. Це найнебезпечніша форма туберкульозу, при якій мікобактерії стають стійкими до двох найважливіших протитуберкульозних препаратів: ізоніазиду та рифампіцину. Хворі на мультирезистентний туберкульоз потребують обов'язкової госпіталізації та лікування, яке триває від 18 до 24 місяців. Лікування складне, дороговартісне, більш токсичне для хворого та менш ефективне [1, 2]. Україна посідає 9 місце за абсолютною кількістю виявлених випадків мультирезистентного туберкульозу у світі. Переважна більшість таких пацієнтів приречена на несприятливий прогноз, а ті, яким призначено паліативне лікування без чітко врегульованого й достатнього соціального й медичного супроводу, взагалі залишаються поза увагою, чим може бути зумовлене неконтрольоване поширення хіміорезистентного туберкульозу [3].

Мета дослідження - з'ясувати частоту і причини поширення мультирезистентного туберкульозу легень за даними медичної документації обласного протитуберкульозного диспансеру.

Матеріал і методи дослідження. В аналіз включено 562 хворих на мультирезистентний туберкульоз легень, що становило 8,5 \% від загальної кількості осіб, які перебували на стаціонарному лікуванні з 2005 по 2014 рік. 3'ясовували вік, стать, місце проживання, тип і клінічні форми туберкульозного процесу, а також тривалість лікування і його результати. На підставі отриманих даних і найбільш вірогідних причин мультирезистентності зроблено висновок щодо зниження поширеності цієї дуже небезпечної форми туберкульозу.

Результати й обговорення. 3а 2005-2014 роки в Тернопільському облтубдиспансері лікувались 562 хворих на мультирезистентний туберкульоз легень. Із загальної кількості пацієнтів чоловіків було 489 (87,0 \%), жінок - 73 (13,0\%); мешканців міст - 220 (39,1\%), села - 331 (58,9\%) і без постійного місця проживання - 11 (2,0%) осіб.
Вік хворих коливався від 17 до 81 року, в середньому становив $(44,0 \pm 1,7)$, зокрема в першому п'ятиріччі - 45,3, а в другому $-43,5$ років.

Отже, найчастіше мультирезистентним туберкульозом страждали чоловіки і мешканці села молодого та середнього віку.

Власне мультирезистентний туберкульоз констатовано у $494(87,9 \%)$ осіб, а розширену резистентність - у 68 (12,1\%), яка за останні роки спостерігається все частіше. За клінічними формами туберкульозу хворі розподілилися таким чином: фіброзно-кавернозний туберкульоз був у 196 (34,9\%), інфільтративний - у 192 (34,2\%), дисемінований - у 171 (30,4 \%), циротичний - у 2 $(0,4 \%)$ і вогнищевий - у $1(0,2 \%)$ пацієнта.

Загалом туберкульоз легень із довготривалим перебігом констатовано у 256 (45,6 \%) осіб, рецидиви - у 199 (35,4 \%) і вперше діагностований туберкульоз -у 107 (19,0 \%) хворих.

До слова, за останні роки значно зросла кількість хворих із рецидивами та вперше діагностованим мультирезистентним туберкульозом. Це зумовлено незавершеним, у більшості випадків короткочасним стаціонарним лікуванням, яке проводилося до припинення виділення мікобактерій за мазком мокротиння, а на амбулаторному етапі не було належного контролю за лікуванням. До того ж, почастішали відмови хворих від стаціонарного лікування. Причиною цього $\epsilon$ незадовільна санітарна грамотність хворих, як і населення в цілому і, як наслідок, відсутність прихильності до лікування [4]. Санпросвітня робота серед хворих, починаючи з моменту виявлення туберкульозу i, головним чином, у період стаціонарного лікування, а також і після виписки зі стаціонару, проводилася на неналежному рівні.

Лікування хворих на мультирезистентний туберкульоз проводилося згідно з Уніфікованим клінічним протоколом [5]. У результаті проведеного лікування покращення констатовано у 192 (34,2 \%) хворих, відсутність особливих змін -у $226(40,2 \%)$, прогресування процесу констатовано у 47 (8,4 \%), померло 97 (17,2 \%) хворих. Зауважимо, що серед- 
Огляди літератури, оригінальні дослідження, погляд на проблему

ня тривалість перебування хворого на мультирезистентний туберкульоз легень у стаціонарі становила всього 139,0 ліжко-днів. Лише 98 (17,4 \%) пацієнтам проводилось лікування 8 і більше місяців. Така тривалість лікування хворих з довготривалим перебігом туберкульозу та рецидивами була у 67 (11,9\%) осіб, а з вперше діагностованим мультирезистентним туберкульозом - у 31 (5,5 \%) пацієнта. Як видно з наведених даних, результати лікування хворих на мультирезистентний туберкульоз доволі мізерні. Короткочасне перебування значної частини хворих у стаціонарі, неповноцінне проведення інтенсивної фази хіміотерапії складно пояснити і виправдати будь-якими мотивами. Хоча тут причиною найвірогідніше $\epsilon$ незадовільна санітарна грамотність самих хворих і їх рідних щодо боротьби з туберкульозом. Прихильність до лікування у пацієнтів повинні прищеплювати медичні працівники на різних рівнях, але передусім - фтизіатри. Зрозуміло, що це нелегка робота, але дуже потрібна. Без належної санітарної грамотності хворих та населення загалом на успіх у боротьбі з туберкульозом сподіватися неможливо. Значна кількість пацієнтів виписана додому на паліативне лікування, але перебування тяжких помираючих хворих у домашніх умовах створює надзвичайно велику загрозу розповсюдження цієї надто небезпечної форми туберкульозу. Звідси і джерело первинної мультирезистентності, почастішання її у сімейних вогнищах.

Пізня діагностика мультирезистентного туберкульозу, рецидивів, як і загострення процесу у «хроніків», характеризується тяжким перебігом, незадовільною ефективністю лікування і високою летальністю (17,2 \%).

\section{ЛІТЕРАТУРА}

1. Ковальова Г. Г. Актуальні питання та практичні підходи до підвищення ефективності Загальнодержавної програми протидії захворюванню на туберкульоз в Україні / Г. Г. Ковальова // Туберкульоз, легеневі хвороби, ВІЛ-інфекція. - 2013. - № 4. - С. 14-23.

2. Hutchinson D. C. Management of multiple drug-resistant tuberculosis / D. C. Hutchinson, F. A. Drobniewski, H. l. Miburn // Respir. Medicine. - 2003. - Vol. 97, N 1.

3. Петренко В. І. До міжнародного дня боротьби з туберкульозом: "Охопити три мільйони: виявити, лікувати, вилікувати туберкульоз" / В. І. Петренко // Тубер-
Із 562 хворих на мультирезистантний туберкульоз померли 97 (17,2 \%) пацієнтів, з них до одного місяця - 31 (32,0\%), до трьох місяців стаціонарного лікування - 63 (64,9 \%) особи. Це свідчить про пізнє виявлення вперше діагностованих хворих, як і тяжкість перебігу процесу у хворих 3 різними типами специфічного процесу.

Проаналізувавши та усунувши недоліки зі сторони загальної медичної служби, і фтизіатричної зокрема, та покращивши матеріальне забезпечення медичних закладів, населення, а також забезпечивши підвищення санітарної грамотності, свідомості людей і хворих можна сподіватися на сповільнення поширення і кращі результати лікування надзвичайно небезпечного мультирезистентного туберкульозу.

Висновки. 1. Кількість хворих на мультирезистентний туберкульоз в області з кожним роком зростає, як серед вперше діагностованих, рецидивів, так і серед осіб з довготривалим хронічним перебігом туберкульозного процесу.

2. Переважна більшість пацієнтів, які страждають на мультирезистентний туберкульоз, - це особи чоловічої статі, мешканці села працездатного віку.

3. Значне поширення мультирезистентного туберкульозу зумовлено пізньою діагностикою, короткочасним стаціонарним і слабо контрольованим амбулаторним лікуванням, а також низькою прихильністю хворих до лікування через незадовільну санітарну грамотність щодо боротьби з туберкульозом хворих і населення в цілому.

У перспективі подальших досліджень вважаємо за доцільне поглиблене вивчення цієї проблеми по окремих регіонах області.

кульоз, легеневі хвороби, ВІЛ-інфекція. - 2014. - № 1. С. 5-7.

4. П'ятночка І. Т. Шляхи зниження розповсюдження мультирезистентного туберкульозу з погляду фтизіоепідеміології / І. Т. П'ятночка, С. І. Корнага, Н. В. Тхорик // Вісник соціальної гігієни та організації охорони здоров'я України. - 2014. - № 4. - С. 67-71.

5. Уніфікований клінічний протокол первинної, вторинної (спеціалізованої) та третинної (високоспеціалізованої) медичної допомоги дорослим. Туберкульоз. - 2014. - 179 с.

\section{MULTI-DRUG RESISTANT TUBERCULOSIS ACCORDING TO THE REGIONAL TB DISPENSARY}

\section{@S. I. Kornaha, I. T. Pyatnochka, N. V. Thoryk \\ I. Horbachevsky Ternopil State Medical University}

SUMMARY. The article presents an analysis of medical records in multidrug-resistant tuberculosis patients who were undergoing treatment in the regional TB dispensary in 2005-2014 years, and provides the reason for the considerable increase of this dangerous form of the disease.

KEY WORDS: multidrug resistant tuberculosis, health education, mortality. 